\title{
Hydrolysis of Residual Starch from Sago Pith Residue and Its Fermentation to Bioethanol
}

(Hidrolisis Sisa Kanji daripada Hampas Sagu serta Fermentasinya kepada Bioetanol)

\author{
NURUl AdEla BUKHARI*, SOH KHEANG LOH, NASRIN ABU BAKAR \& MAIZAN ISMAIL
}

\begin{abstract}
Utilisation of sago pith residue (SPR) for fermentable sugar production using both acid and enzymatic hydrolysis was studied. In acid hydrolysis, the effect of solid and acid concentrations, temperature and reaction time was optimised. The effect of enzyme dosage was studied on enzymatic hydrolysis of SPR. Higher yield and conversion of $0.73 \mathrm{~g} \mathrm{~g}^{-1}(96 \%$ conversion) was achieved by treating $6 \%\left(w v^{-1}\right)$ of SPR with $1 \%\left(v v^{-1}\right) \mathrm{H}_{2} \mathrm{SO}_{4}$ at $125^{\circ} \mathrm{C}$ for 90 min as compared to 0.61 $\mathrm{g} \mathrm{g}^{-1}$ (79\% conversion) using $40 \mathrm{U} \mathrm{g}^{-1}$ biomass of Aspergillus niger amyloglucosidase incubated at $60^{\circ} \mathrm{C}$ and $\mathrm{pH} 4$ for $48 \mathrm{~h}$. The fermentation of acid hydrolysate of SPR demonstrated that high ethanol yield of $98 \%$ can be achieved without supplementation of nitrogen and nutrients. The complete process showed that $470 \mathrm{~L}$ of bioethanol could be produced from 1 tonne of SPR. This figure makes SPR an ideal raw material for bio-conversion into bioethanol or other value-added products.
\end{abstract}

Keywords: Acid hydrolysis; bioethanol; enzymatic hydrolysis; fermentation; sago pith residue

ABSTRAK

Penggunaan hampas sagu (SPR) untuk penghasilan gula menggunakan hidrolisis asid dan enzim telah dikaji. Dalam hidrolisis asid, kesan kepekatan pepejal dan asid, suhu dan masa tindak balas telah dioptimumkan. Kesan dos enzim pula dikaji dalam hidrolisis enzim terhadap SPR. Hasil yang lebih tinggi dengan penukaran sebanyak $0.73 \mathrm{~g}^{-1}(96 \%$ penukaran) telah dicapai dengan merawat $6 \%\left(w v^{-1}\right)$ hampas sagu menggunakan $1 \%\left(v v^{-1}\right) \mathrm{H}_{2} \mathrm{SO}_{4}$ pada $125^{\circ} \mathrm{C}$ selama 90 min berbanding dengan $0.61 \mathrm{~g} \mathrm{~g}^{-1}$ (79\% penukaran) menggunakan $40 \mathrm{U} \mathrm{g}^{-1}$ amiloglukosidase Aspergillus niger yang dieram pada $60^{\circ} \mathrm{C}$, pH4 selama 48 jam. Fermentasi hidrolisat asid hampas sagu menunjukkan hasil etanol yang tinggi iaitu sebanyak $98 \%$ boleh dicapai tanpa penambahan nitrogen dan nutrien. Proses bio-penukaran lengkap menunjukkan 470 L bioetanol boleh dihasilkan daripada 1 tan hampas sagu. Hasil yang diperoleh ini mencadangkan hampas sagu sebagai bahan mentah yang sesuai untuk bio-penukaran kepada bioetanol atau produk nilai tambah yang lain.

Kata kunci: Bioetanol; fermentasi; hampas sawit; hidrolisis asid; hidrolisis enzim

\section{INTRODUCTION}

Sago palm (Metroxylon sagu, Rottb.) is considered as a forgotten crop and yet a crop par excellence. Sago palm has many agronomic advantages - it is extremely hardy, thrives in swampy, acidic peat soil, submerged and saline soils where only few crops survive and is immune to floods, drought, fire and strong winds (Hisajima 1994; Singhal et al. 2008). Sago stands as an excellent sink for carbon sequestration, thereby offsetting the greenhouse gas effect making it a very important plant resource for environmental remediation. It is unique in its perennial nature; yields starch continuously without any need to replant and grows well with no or minimal external input and management practices, thus leading to low environmental impact (Flores 2009; Gusmayanti et al. 2010).

In Malaysia, sago palm estates are mostly found in Sarawak. The number of sago palm plantations has increased due to the development of state governmentsubsidized scheme along with existing wild stands in the coastal area. In 2013, the total sago planted area was estimated to be 54,087 ha in Sarawak and nearly 47,946 tonnes of sago starch was exported mainly to Peninsular Malaysia, Japan, Singapore and Thailand (Sarawak Agriculture Statistics 2013). Its calculated productivity is up to 15 tonnes per ha per year of starch. This yield is much higher compared to the yields of other starchy crops such as rice $\left(6 \mathrm{t} \mathrm{ha}^{-1}\right)$ and corn $\left(5.5 \mathrm{t} \mathrm{ha}^{-1}\right)$ (Gusmayanti et al. 2010). As sago is highly productive, the conversion of sago-based starch rich in cellulose into bioethanol as an alternative energy source is believed to be sustainable and environmentally-friendly.

In most bioethanol production, the limiting factor is the cost of deriving glucose from starchy and cellulosic materials. If there is a way by which the fermentation can be short-cut from starch/cellulose directly to alcohol in a single step using a single microorganism, the process will be more attractive and viable (Flores 2009). However, the optimum growth of the microorganisms employed in a single step bioprocess would be different and may result in lower efficiency and product yield. Hence, a more efficient 
ethanol process i.e. separate hydrolysis and fermentation (SHF) approach is preferred (Gupta et al. 2012; Kuhad et al. 2010). Continuous efforts are being made to develop the bioprocess that can bring down the cost of alternative biofuels to establish a second generation biofuels industry. In sago extraction, a large portion of solid residue remaining consists of fibres and unextracted starch. Approximately one tonne of sago pith residue (SPR) is generated for every tonne of sago starch produced (dry weight basis) as reported by sago manufacturers. Currently, this residue is usually combined with wastewater generated and discarded into rivers. This has resulted in poor water quality and has endangered aquatic lives due to microbiological degradation of the waste. As the oxygen dissolved in the water is consumed, the water is left with insufficient oxygen to support higher forms of life (Cecil 2002). This is wasteful as SPR is a valuable biomaterial and is abundantly available.

SPR has a unique characteristic as it is composed mostly of polysaccharides i.e. starch $(65 \%)$ and cellulose (15\%) amounting to $80 \%$ of its total weight. As SPR contains high amounts of residual starch, it is beneficial to utilize it as feedstock for bioethanol conversion. This present study shows complete utilization of SPR in its processing chain. It is demonstrated that an almost complete conversion of SPR into bioethanol was possible by investigating the influence of several factors on acid and enzymatic hydrolysis of SPR. The derived sugar from hydrolyzed SPR was subsequently fermented to produce bioethanol. Compositional and microscopic analysis was also carried out to provide a better understanding of this bioconversion process.

\section{MATERIALS AND METHODS}

\section{RAW MATERIAL}

Dried SPR was obtained from CRAUN Research in Kuching, Sarawak, Malaysia. The sample was dried at $80^{\circ} \mathrm{C}$ for 24 $\mathrm{h}$, ground into smaller pieces using a grinder machine and sieved to obtain particles having a size between 200 and $300 \mu \mathrm{m}$. It was stored at room temperature prior to conversion. The enzyme, amyloglucosidase derived from Aspergillus niger $\left(70 \mathrm{U} \mathrm{mg}^{-1}\right)$ was purchased commercially (Sigma, Switzerland).

\section{HYDROLYSIS OF SPR}

For acid hydrolysis, the dried ground SPR at 5, 6, 7, 8,9 and $10 \%\left(\mathrm{w} \mathrm{v}^{-1}\right)$ were suspended in $\mathrm{H}_{2} \mathrm{SO}_{4}$ solution at different concentrations ranging from $0.1-2.0 \%\left(\mathrm{v} \mathrm{v}^{-1}\right)$. The optimal solid and acid concentrations were then employed in determining the temperature $\left(105\right.$ and $\left.125^{\circ} \mathrm{C}\right)$ and reaction time $(30,60,90$ and $120 \mathrm{~min})$ of acid hydrolysis. The samples were hydrolysed in an autoclave (Hirayama HVE50 , Japan) at selected temperature and reaction time and the hydrolysate was subsequently collected and analysed for the content of sugars. For enzymatic hydrolysis, the dried ground SPR at the optimised solid loading i.e. $6 \%$ $\left(\mathrm{W} \mathrm{V}^{-1}\right.$ ) was suspended in $0.1 \mathrm{M}$ citrate buffer (pH4.0) and gelatinised at $90^{\circ} \mathrm{C}$ for $15 \mathrm{~min}$ in a water bath. The samples were then cooled to $60^{\circ} \mathrm{C}$ prior to amyloglucosidase addition (10-50 $\mathrm{U} \mathrm{g}^{-1}$ biomass) to avoid denaturation. The samples were then incubated at $60^{\circ} \mathrm{C}, 150 \mathrm{rpm}$ for $48 \mathrm{~h}$ in a rotary incubator shaker (Innova-40, New Brunswick Scientific, USA). Sample aliquots were withdrawn at 6, 24 and $48 \mathrm{~h}$ intervals and analyzed for the released sugars.

\section{FERMENTATION OF SPR HYDROLYSATE}

The fermentation of SPR hydrolysate was carried out in a 6.7-L bench-scale bioreactor (Bioengineering, Switzerland) coupled with SCADA software, with a working fermentation medium (SPR hydrolysate) of 3.0 L. The $\mathrm{pH}$ of working medium was first corrected using $10 \mathrm{M} \mathrm{NaOH}$ to a desired $\mathrm{pH}$ of 4.0. No additional source of nitrogen was added in this study. The bioreactor together with the SPR hydrolysate was sterilized by autoclaving at $121^{\circ} \mathrm{C}$ for 30 min. The sterile medium was then inoculated with $10 \%$ (v $\mathrm{V}^{-1}$ ) log-phase culture of $S$. cerevisiae ATCC 24860 (approx. $18 \mathrm{~h}$ of incubation at $30^{\circ} \mathrm{C}, 100 \mathrm{rpm}$ ). The fermentation was carried out in batch mode at $\mathrm{pH} 4.0,30^{\circ} \mathrm{C}$ and 100 rpm with mixing using two parallel Rushton turbines for 2 days. Fermentation time was determined from the moment of inoculation and samples were taken at predetermined time intervals for analysis.

The bacterial growth was estimated according to NurulAdela et al. (2016). The oD of the fermentation broth at 600 $\mathrm{nm}$ was measured using a UV-visible spectrophotometer (Genesys 20, Thermo Scientific, USA) and then converting it to cell dry weight (CDW) $(\mathrm{g} / \mathrm{L})$ as biomass concentration. The culture broth was centrifuged at $4000 \mathrm{rpm}$ for $10 \mathrm{~min}$ to separate the cells. The supernatant was removed and the cells dried at $80^{\circ} \mathrm{C}$ to a constant weight as a measurement of cell growth. The standard curve was prepared based on OD 600 versus CDW. The prepared standard curve had a linear regression of $\mathrm{y}=0.5 \mathrm{x}+0.0555$ with $\mathrm{R}^{2}=0.9986$.

\section{ANALYTICAL METHOD}

The chemical composition of SPR i.e. holocellulose, $\alpha$-cellulose and lignin of SPR was analyzed according to the American Society for Testing Materials (ASTM) 110456, ASTM D1103-60 and Technical Association of the Pulp and Paper Industry (TAPPI) T222 om-1, respectively. The moisture and ash content ( $\%$ on dry basis) were determined using thermogravimetric analyzer (TGA710, LECO, USA). The sample was heated from room temperature to $107^{\circ} \mathrm{C}$ for $120 \mathrm{~min}$ and $750^{\circ} \mathrm{C}$ for $120 \mathrm{~min}$ for its moisture and ash content, respectively. The raw, acid and enzyme hydrolyzed biomass samples were subjected to microscopic study using scanning electron microscope (SEM). The hydrolyzed sample was filtered and washed prior to drying at $80^{\circ} \mathrm{C}$ for $24 \mathrm{~h}$. The dried sample was analyzed using a Hitachi S-3400N model SEM with Energy-dispersive X-ray spectroscopy (Horiba EMAX EDX) (SEM-EDX) under backscattered electrons (BSE) mode with $15 \mathrm{kV}$. 


\section{PRODUCT QUANTIFICATION}

Sugars and ethanol concentrations were analyzed using high performance liquid chromatography (HPLC) (Waters 2707). Sugar Pack ${ }^{\mathrm{TM}}$ column was used for the analysis. The samples were filtered through $0.45 \mu \mathrm{m}$ nylon membrane filters and injected into the column. Deionized water was used as the mobile phase with flow rate of $0.5 \mathrm{~mL} \mathrm{~min}^{-1}$. The column temperature was maintained at $75^{\circ} \mathrm{C}$.

For hydrolysis, the sugars yield $\left(\mathrm{g} \mathrm{g}^{-1}\right)$ was calculated based on the experimental sugars produced and expressed as $g$ sugars per total $\mathrm{g}$ of solid loading (1). The hydrolysis conversion or recovery (\%) was calculated based on the amount of sugars obtained from the hydrolysis of starch (2).

$$
\begin{aligned}
& \text { Sugar yield } \\
& \left(\mathrm{g} \mathrm{g}^{-1}\right)
\end{aligned}=\frac{\text { Concentration of glucose }\left(\mathrm{g} \mathrm{L}^{-1}\right)}{\text { Concentration of SPR }\left(\mathrm{g} \mathrm{L}^{-1}\right)} \text {. }
$$

$$
\begin{aligned}
& \begin{array}{l}
\text { Hydrolysis } \\
\text { conversion }
\end{array}= \\
& \begin{aligned}
(\%) & \frac{\text { Concentration of glucose }\left(\mathrm{g} \mathrm{L}^{-1}\right)}{\text { Concentration of SPR }\left(\mathrm{g} \mathrm{L}^{-1}\right)} \times 100 . \\
& \times(0.689 \times 1.11)
\end{aligned}
\end{aligned}
$$

The value of 0.689 refers to the residual starch content in SPR which is $68.9 \%$ of weight and a complete hydrolysis of $1 \mathrm{~g}$ starch yields $1.11 \mathrm{~g}$ glucose (theoretical value) due to reaction with water.

For fermentation, the ethanol yield $\left(\mathrm{g} \mathrm{g}^{-1}\right)$ was calculated based on the experimental ethanol produced and expressed as g ethanol per total $g$ of sugar utilized (3) and the theoretical ethanol yield (fermentation efficiency) (\%) was calculated based on the ratio of ethanol yield $\left(\mathrm{g} \mathrm{g}^{-1}\right)$ obtained against the theoretical maximum ethanol yield, $0.51 \mathrm{~g}$ ethanol per g glucose (4). The ethanol productivity was calculated based on the ethanol produced against fermentation time (5),

$$
\text { Ethanol yield }\left(\mathrm{g} \mathrm{g}^{-1}\right)=\frac{\text { Concentration of ethanol }\left(\mathrm{g} \mathrm{L}^{-1}\right)}{\text { Concentration of glucose }\left(\mathrm{g} \mathrm{L}^{-1}\right)} \text {. }
$$

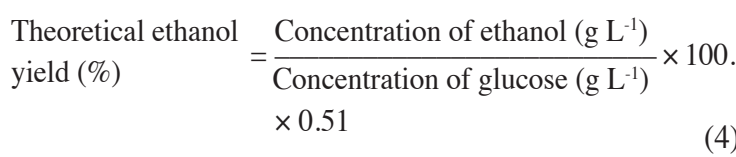

Ethanol productivity $=\frac{\text { Concentration of ethanol }\left(\mathrm{g} \mathrm{L}^{-1}\right)}{\text { Fermentation time }(\mathrm{h})}$.

\section{STATISTICAL ANALYSIS}

All the experiments were carried out in triplicate and the data was analyzed using Minitab ${ }^{\circledR} 16$ by performing an analysis of variance (ANOVA) followed by Tukey's multiple comparison test. Level of statistical significance was set at $5 \%(p<0.05)$.

\section{RESULTS AND DISCUSSION}

\section{SPR COMPOSITION ANALYSIS}

Compositional analysis of SPR showed that it contained $23.69 \pm 0.69 \%$ of holocellulose; of which $11.78 \pm 0.25 \%$ was $\alpha$-cellulose and the other $11.91 \pm 0.43 \%$ hemicellulose. The other components, lignin and ash were relatively low at $5.05 \pm 1.35 \%$ and $2.35 \pm 0.08 \%$, respectively. The calculated starch $68.92 \pm 2.12 \%$ was similar with those reported earlier ranging from 58 to $70 \%$ (Table 1). The amount and quality of residual starch in SPR depends on the extraction method employed (Siti Mazlina et al. 2007). As SPR contains residual starch and is low in lignin and ash, it is considered as an excellent feedstock for microbial conversion into various value products such as bioethanol.

\section{ACID HYDROLYSIS}

In order to produce bioethanol from SPR, the breakdown of starch into fermentable sugar is necessary. In hydrolyzing the residual starch in SPR, the acid acts as the catalyst to break the glycosidic bonds of the starch to produce dextrin, maltotriose, maltose and glucose depending on the location of the bond being attacked (Kumoro et al.

TABLE 1. Chemical composition of sago pith residue (SPR)

\begin{tabular}{lccccc}
\hline Component $(\%)$ & \multicolumn{5}{c}{ SPR from different sources } \\
\hline Holocellulose & $23.69 \pm 0.69$ & 31.69 & 14.8 & 32.2 & 15 \\
$\quad$ Cellulose & $11.78 \pm 0.25$ & $23.5 \pm 1.0$ & - & 23.0 & - \\
$\quad$ Hemicellulose & $11.91 \pm 0.43$ & $8.19 \pm 0.2$ & - & 9.2 & - \\
Lignin & $5.05 \pm 1.35$ & $6.3 \pm 1.0$ & n.a. & 3.9 & n.a. \\
Ash & $2.35 \pm 0.08$ & $1.7 \pm 0.1$ & 4.10 & n.a. & 4.16 \\
Starch & $68.92 \pm 2.12^{*}$ & $58.0 \pm 1.2$ & 65.7 & 58 & 70 \\
Moisture & $12.50 \pm 0.01$ & n.a. & 5.91 & n.a. & n.a. \\
References & This study & Vincent et al. & Vickineswary and & Ozawa et al. & Kumoro et al. \\
& & $(2015)$ & Shim (1996) & (1996) & 2008 \\
\hline
\end{tabular}

n.a. - not available

* calculated by weight difference 
2008). Four parameters affecting acid hydrolysis i.e. solid loading, acid concentration, reaction time and temperature were optimized. Figure 1 shows the effect of different solid loading on SPR hydrolysis. A maximum sugar yield of $0.748 \pm 0.05 \mathrm{~g} \mathrm{~g}^{-1}$ SPR was attained at $6 \%\left(\mathrm{w} \mathrm{v}^{-1}\right)$ solid concentrations. However, the effect of solid concentration was insignificant in influencing the release of sugar during hydrolysis $(p=0.544)$. This may be due to the narrow range used in this study (i.e. 1\% difference). Awg-Adeni et al. (2013) reported that the conversion yield starts to decline at $9 \%\left(\mathrm{w} \mathrm{v}^{-1}\right)$ solid concentration which showed that the hydrolysis reaction at high solid leads to increased viscosity and poor heat transfer due to rheological properties of dense suspension (Gupta et al. 2012).

Figure 2 shows increased hydrolyzed sugar yields with increasing acid concentration in a hyperbola trend. The $\mathrm{H}_{2} \mathrm{SO}_{4}$ at concentrations $\geq 1 \%\left(\mathrm{v} \mathrm{v}^{-1}\right)$ was found efficient in hydrolyzing SPR. The sugar yield increased from 0.03 $\mathrm{g} \mathrm{g}^{-1}$ at $0.1 \%\left(\mathrm{v} \mathrm{v}^{-1}\right) \mathrm{H}_{2} \mathrm{SO}_{4}$ to 0.41 and $0.55 \mathrm{~g} \mathrm{~g}^{-1}$ at 0.5 and $0.7 \%\left(\mathrm{v} \mathrm{v}^{-1}\right) \mathrm{H}_{2} \mathrm{SO}_{4}$, respectively, from the hydrolyzed SPR. By increasing the acid concentration at a constant heating rate, there was a gradual increase in the released sugar before an optimum of $0.71 \mathrm{~g} \mathrm{~g}^{-1}$ at $2 \%\left(\mathrm{v} \mathrm{v}^{-1}\right)$ concentration. The increase in the catalyzing ability of hydrogen ions in $\mathrm{H}_{2} \mathrm{SO}_{4}$ to hydrolyze the C5-C6 monomer from the polymers suggests a lower activation energy for hydrolysis (Khawla et al. 2014). This resulted in an increase in the rate of hydrolysis of SPR with increasing acid concentration leading to higher released sugar yield before reaching a plateau at $1 \%\left(\mathrm{v} \mathrm{v}^{-1}\right)$. Thus, $\mathrm{a}_{2} \mathrm{SO}_{4}$ concentration of $1 \%$ $\left(\mathrm{v} \mathrm{v}^{-1}\right)$ was considered the best for further experiments.

The temperature and reaction time explored to optimize the acid hydrolysis of SPR were 105 and $125^{\circ} \mathrm{C}$ for 30,60 , 90 and $120 \mathrm{~min}$, respectively. An increase in reaction time of acid hydrolysis from 30 to 120 min gradually increased the sugar yield at $105^{\circ} \mathrm{C}$ (Figure 3 ). The sugar yield increased significantly $(p<0.05)$ i.e. $0.275,0.514,0.588$ and $0.711 \mathrm{~g} \mathrm{~g}^{-1}$ corresponding to $35.9,37.2,76.9$ and $97.0 \%$ hydrolysis conversion at each predetermined interval (30, 60, 90 and $120 \mathrm{~min}$ ), respectively (Table 2). Following this trend, it may be possible to achieve higher yield at this temperature if the hydrolysis time were extended.

On the other hand, hydrolysis of SPR at $125^{\circ} \mathrm{C}$ showed better sugar yield than at $105^{\circ} \mathrm{C}$ with a shorter reaction time. The maximum yield was $0.73 \mathrm{~g} \mathrm{~g}^{-1}$ achieved within 90 min. However, it did not significantly increase the released sugar with the increasing of reaction time from 30 to 120 min (Table 2). When one-way ANOVA was conducted to compare the levels of hydrolysis at various reaction time using a Tukey's multiple comparison test, the hydrolysis

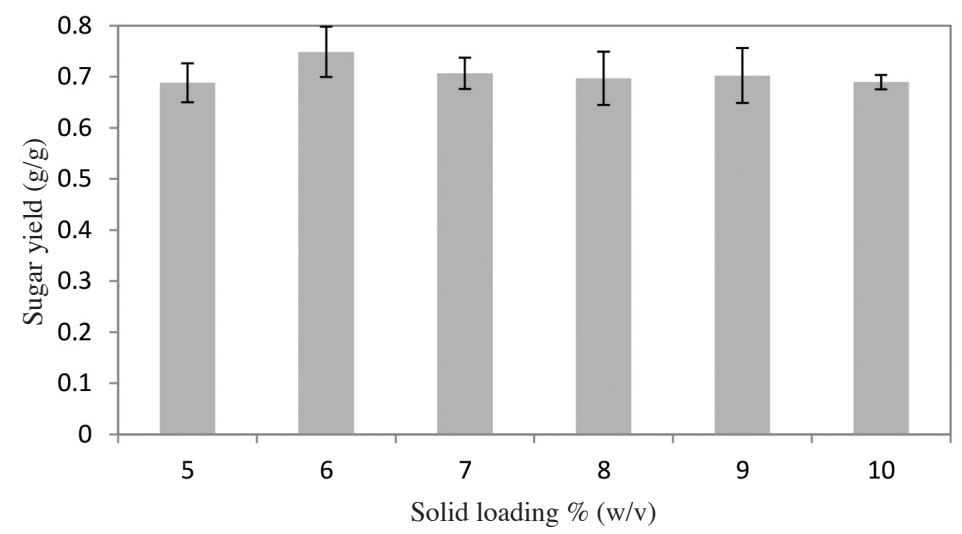

FIGURE 1. Effect of different solid concentrations on sago pith residue hydrolysis

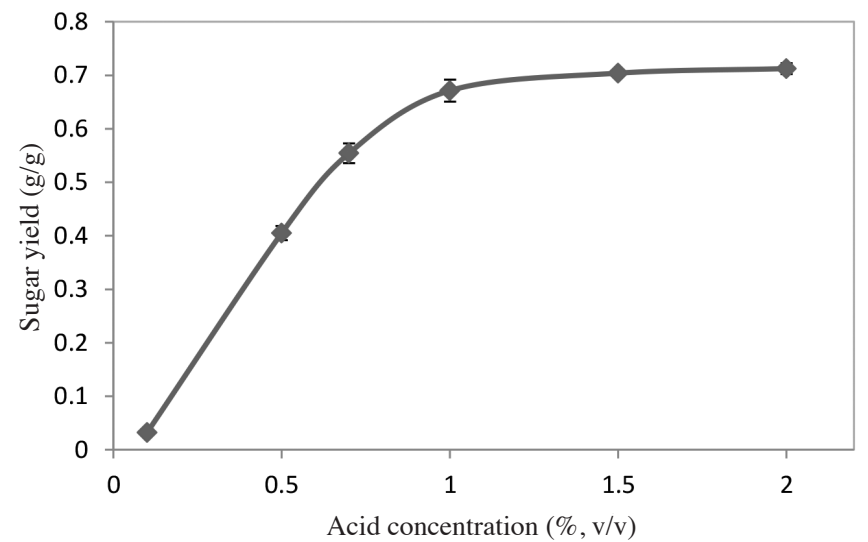

FIGURE 2. Effect of different acid concentrations on sago pith residue hydrolysis 
at 30,60 and 90; and 30,60 and 120 did not significantly different. Therefore, we concluded that using higher temperatures to enhance the yield is more efficient than lengthening the reaction time. An elevated temperature provides greater energy to break down the linkages existing in SPR, leading to higher sugar yield (Kootstra et al. 2009; Kumoro et al. 2008).

\section{ENZYMATIC HYDROLYSIS}

The enzymes during hydrolysis of SPR act as catalysts to break down the glycosidic bonds of the starch to produce glucose. However, before enzymes can hydrolyze the starch, it must be gelatinized by heating at $90^{\circ} \mathrm{C}$ for $15 \mathrm{~min}$ (Awg-Adeni et al. 2013). The gelatinization process is crucial to obtain high hydrolysis yield prior to saccharification. The presence of water in the gelatinization process allows breakdown of intermolecular bonds within the starch molecules with the assistance of temperature, thus providing free sites for hydrogen bonding and attraction of more water molecules. This enhances the randomness of the fibre structure, reduces crystallinity and allows more water to penetrate. Upon heating, the resulting amorphous region will diffuse, leading to chain disengagement. As a result, SPR is softened and becomes more susceptible to enzymatic attack (Kumoro et al. 2008).

During saccharification of the partially-hydrolyzed SPR, the amyloglucoside employed hydrolysed, the terminal $\alpha-1,4-$ and $\alpha-1,6$ glucosidic bonds (glucoseglucose bonds) in starch, hence completely degrading and removing glucose units sequentially from the nonreducing end of the molecule. The influence of enzyme dosage towards SPR hydrolysis was investigated. Figure 4 shows that sugar yield from SPR increased with the increase in enzyme dosage over $24 \mathrm{~h}$. Only glucose was produced throughout the hydrolysis process as the amyloglucosidase hydrolysed the $\alpha-1,4$ links very efficiently and a much slower rate for $\alpha-1,6$ links (Hii et al. 2012). The increase of enzyme dosage from 10 to $50 \mathrm{U} \mathrm{g}^{-1}$ significantly improved the glucose yield during the first $6 \mathrm{~h}$ of reaction $(p=0.001)$. At the 24 th and 48 th $\mathrm{h}$, the glucose yield at 20-50 $\mathrm{U} \mathrm{g}^{-1}$ of enzyme dosage was insignificant. The highest glucose yield was 0.61 $\mathrm{g} \mathrm{g}^{-1}$ which corresponded to $79.4 \%$ of starch to sugar conversion using $40 \mathrm{U} \mathrm{g}^{-1}$ amyloglucosidase for $48 \mathrm{~h}$. The increment in enzyme dosage from 20 to $50 \mathrm{U} \mathrm{g}^{-1}$ did not give better glucose yield as too much enzyme may

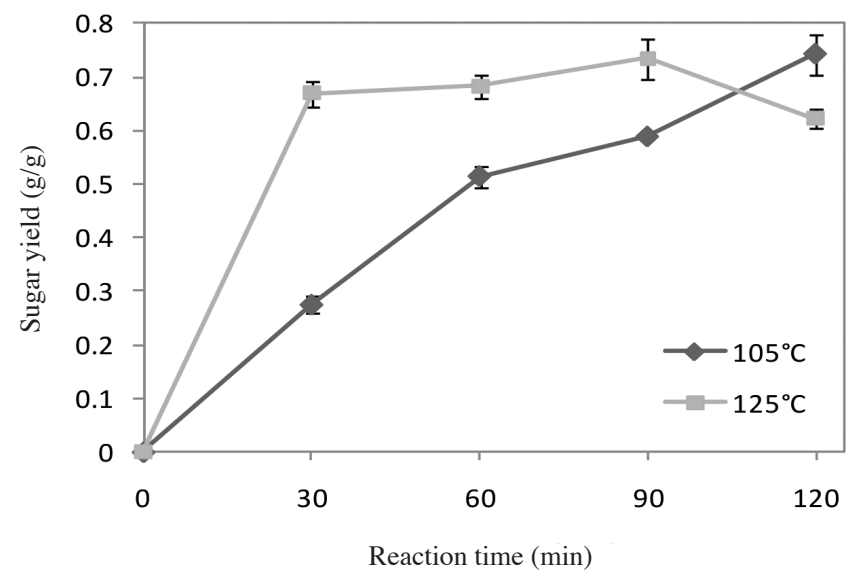

FIGURE 3 . The profile of fermentable sugar yields at different temperatures and reaction times

TABLE 2. Effect of different variables (time and temperature) on the released sugars during acid hydrolysis of sago pith residue

\begin{tabular}{|c|c|c|c|c|c|}
\hline $\begin{array}{r}\text { Temperature }\left({ }^{\circ} \mathrm{C}\right) / \\
\text { Time }(\mathrm{min})\end{array}$ & $\begin{array}{c}\text { (Glucose) } \\
(\mathrm{g} / \mathrm{L})\end{array}$ & $\begin{array}{l}\text { (Fructose) } \\
(\mathrm{g} / \mathrm{L})\end{array}$ & $\begin{array}{c}\text { Total (Hexose }) \\
(\mathrm{g} / \mathrm{L})\end{array}$ & $\begin{array}{c}\text { Sugar yield } \\
(\mathrm{mg} / \mathrm{g})\end{array}$ & $\begin{array}{c}\text { Conversion } \\
(\%)\end{array}$ \\
\hline \multicolumn{6}{|l|}{$105^{\circ} \mathrm{C}$} \\
\hline 30 & $15.47 \pm 0.91 \mathrm{a}$ & $1.02 \pm 0.03 \mathrm{a}$ & $16.49 \pm 0.88 a$ & 274.8 & 35.93 \\
\hline 60 & $29.90 \pm 1.14 b$ & $0.96 \pm 0.13 b$ & $30.86 \pm 1.18 b$ & 514.3 & 67.23 \\
\hline 90 & $34.38 \pm 0.12 c$ & $0.91 \pm 0.05 b$ & $35.29 \pm 0.13 c$ & 588.2 & 76.88 \\
\hline 120 & $43.24 \pm 2.25 \mathrm{~d}$ & $1.30 \pm 0.03 b$ & $44.54 \pm 2.22 \mathrm{~d}$ & 742.2 & 97.03 \\
\hline \multicolumn{6}{|l|}{$125^{\circ} \mathrm{C}$} \\
\hline 30 & $39.14 \pm 1.51 \mathrm{a}$ & $1.05 \pm 0.09 a$ & $40.19 \pm 1.45 \mathrm{a}$ & 669.8 & 87.56 \\
\hline 60 & $39.89 \pm 1.40 \mathrm{a}, \mathrm{b}$ & $1.06 \pm 0.03 a$ & $40.95 \pm 1.40 \mathrm{a}, \mathrm{b}$ & 682.5 & 89.21 \\
\hline 90 & $43.01 \pm 2.28 \mathrm{a}, \mathrm{b}$ & $1.02 \pm 0.07 \mathrm{a}$ & $44.03 \pm 2.34 \mathrm{a}, \mathrm{b}$ & 733.8 & 95.92 \\
\hline 120 & $36.31 \pm 1.22 b$ & $1.02 \pm 0.04 \mathrm{a}$ & $37.33 \pm 1.19 b$ & 622.2 & 81.33 \\
\hline
\end{tabular}

Mean values that do not share a letter are significantly different $(p \leq 0.05)$ 
inhibit the hydrolysis reactivity due to the inhibition of polyphenols in the SPR and accumulation of branched chain $\alpha$-1,6-linked oligosaccharides which were more difficult to be hydrolyzed compared to its straight counterparts (Table 3) (Polakovič \& Bryjak 2004). Thus, addition of a de-branching enzyme such as pullulanase can be further applied to aid saccharification process in order to achieve higher yield. Pullulanase has been utilized to hydrolyze the $\alpha-1,6$ glucosidic links in starch, amylopection, pullulan and related oligosaccharides enables a complete and efficient conversion of the branched polysaccharides into simple fermentable sugars (Hii et al. 2012). During saccharification, partially-hydrolyzed amylose and amylopectin molecules are depolymerized by the action of amyloglucosidase which removes glucose units in a step-wise manner from the nonreducing chain ends. The rate of hydrolysis by amyloglucosidase depends on the particular linkage, size of molecule and the order in which $\alpha-1,4$ and $\alpha-1,6$ links are arranged (Hebeda et al. 1993).

\section{MICROSCOPIC ANALYSIS}

The changes in morphology and elemental content of raw SPR before and after acid and enzymatic hydrolysis were examined under SEM. Microscopic observation showed that SPR is composed of a mixture of sago starch and fibre (Figure 5(a)). A large number of starch granules (prolate spheroid in shape with a diameter of 20-40 $\mu \mathrm{m}$ ) were trapped within the sago scrap (Figure 5(b)) and some of them were available freely in the sample (Figure 5(c)). After being treated with acid (Figure 6a) and enzyme (Figure 6b), the starch granules disappeared. This suggested that the acid and enzyme used in this study had hydrolyzed and disrupted all the starch, leading to high starch to sugar conversion. The lignocellulose in SPR fibre consisted of white spiny spherical silica bodies with a diameter of 10-15 $\mu \mathrm{m}$ on its surface (Figure 5(d)). Further details of the elemental compositions of raw SPR showed that it contained $7.8 \%$ silica as shown in EDX analysis (Figure 7). In this study, only the starchy material was

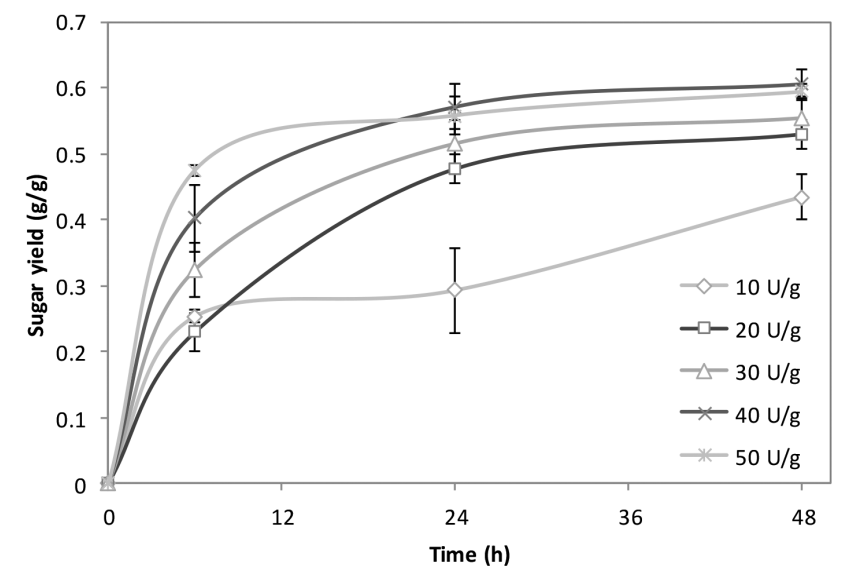

FIGURE 4. Effect of enzyme dosage on sugar released during hydrolysis

TABLE 3. Effect of enzyme dosage on the release of sugars during enzymatic hydrolysis of sago pith residue

\begin{tabular}{ccccc}
\hline $\begin{array}{c}\text { Time } \\
(\mathrm{h})\end{array}$ & $\begin{array}{c}\text { Enzyme dosage } \\
\left(\mathrm{U} \mathrm{g}^{-1} \text { biomass }\right)\end{array}$ & $\begin{array}{c}\text { Glucose } \\
(\mathrm{g} / \mathrm{L})\end{array}$ & $\begin{array}{c}\text { Yield } \\
(\mathrm{mg} / \mathrm{g})\end{array}$ & $\begin{array}{c}\text { Conversion } \\
(\%)\end{array}$ \\
\hline 6 & 10 & $15.19 \pm 3.94 \mathrm{c}$ & 253.17 & 33.09 \\
& 20 & $13.77 \pm 2.52 \mathrm{c}$ & 229.50 & 30.00 \\
& 30 & $19.45 \pm 3.49 \mathrm{~b}, \mathrm{c}$ & 324.17 & 52.38 \\
& 40 & $24.16 \pm 4.32 \mathrm{a}, \mathrm{b}$ & 402.67 & 62.20 \\
24 & 50 & $28.55 \pm 0.68 \mathrm{a}$ & 475.83 & 38.26 \\
& 10 & $17.56 \pm 5.49 \mathrm{~b}$ & 292.67 & 62.35 \\
& 20 & $28.62 \pm 1.89 \mathrm{a}$ & 477.00 & 67.41 \\
& 30 & $30.94 \pm 3.10 \mathrm{a}$ & 515.67 & 74.66 \\
& 40 & $34.27 \pm 2.94 \mathrm{a}$ & 571.17 & 72.98 \\
& 50 & $33.50 \pm 2.49 \mathrm{a}$ & 558.33 & 56.78 \\
& 10 & $26.06 \pm 2.87 \mathrm{~b}$ & 434.33 & 69.22 \\
& 20 & $31.77 \pm 1.93 \mathrm{a}, \mathrm{b}$ & 529.50 & 72.46 \\
& 30 & $33.26 \pm 2.69 \mathrm{a}$ & 554.33 & 79.43 \\
& 40 & $36.34 \pm 1.90 \mathrm{a}$ & 607.67 & 77.70 \\
\hline
\end{tabular}

Mean values that do not share a letter are significantly different $(p \leq 0.05)$ 
hydrolysed by amyloglucosidase and the lignocellulose remained intact. Thus, further hydrolysis of cellulosic residue using cellulase enzyme can be applied to achieve a complete conversion of SPR into fermentable sugars by breaking the 1,4- $\beta$-D-glycosidic linkage (Vincent et al. 2015). Vincent et al. (2015) studies a process in which the starchy material was first liquefied and saccharides, followed by the hydrolysis of cellulosic residue using cellulase via sequential saccharification and simultaneous fermentation (SSSF). However, as silica may physically impact enzymatic attack, in this case, an effective removal of the silica during pretreatment is necessary to enhance the digestibility of SPR fibre.

\section{FERMENTATION OF SPR}

The SPR hydrolysate contained substantial sugars to be fermented into bioethanol. As $S$. cerevisiae is capable of fermenting hexoses/glucose into ethanol, it was used to assess the fermentability of SPR in a 6.7-L bioreactor. SPR from acid hydrolysis was used in this study due to higher glucose obtained in the hydrolysate. Bioethanol production
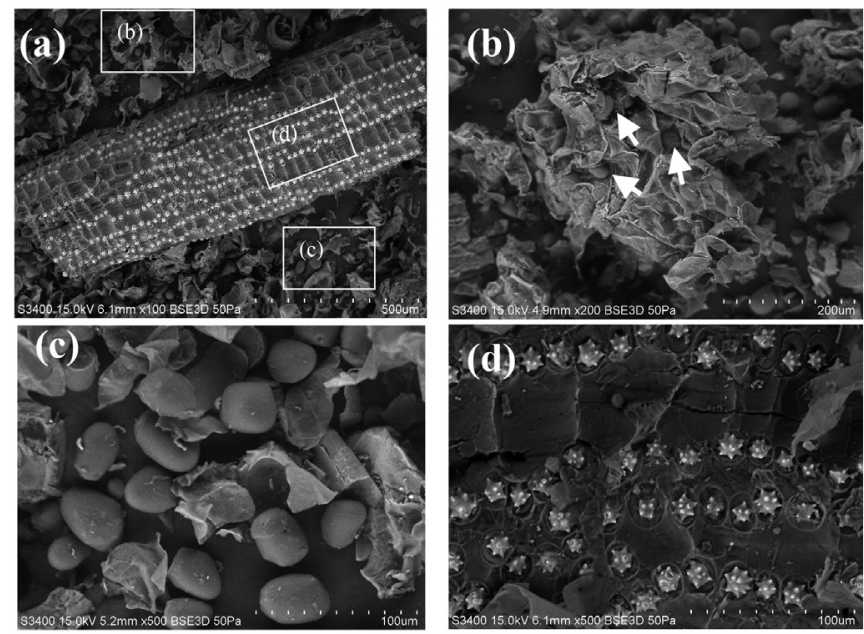

FIGURE 5. SEM micrographs of raw sago pith residue at 100× (a), $200 \times$ (b) and 500× magnification (c \& d)
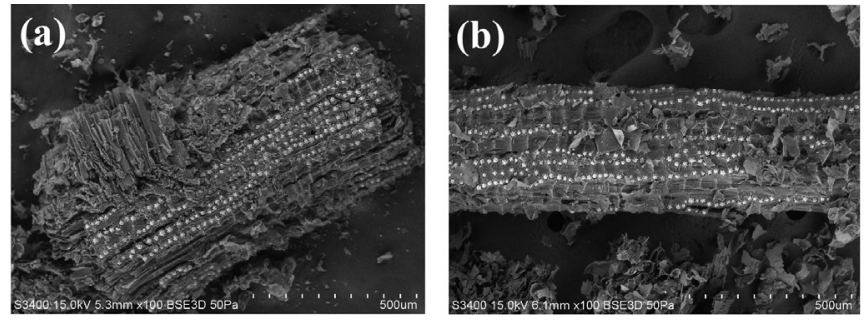

FIGURE 6. SEM micrographs of acid (a) and enzyme (b) treated sago pith residue at $100 \times$ magnification

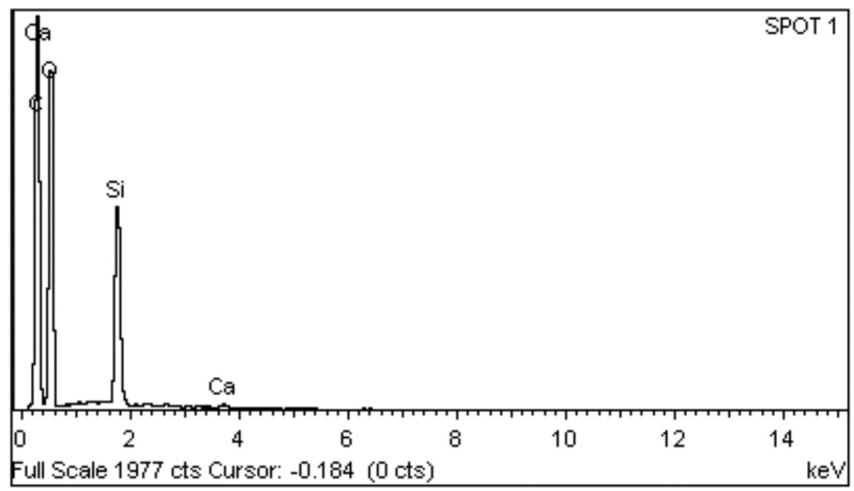

FIGURE 7 . The chemical compositions of raw sago pith residue by energy-dispersive $\mathrm{x}$-ray (EDX) analysis 
gradually increased from the beginning of fermentation to reach a maximum of $27.3 \mathrm{~g} \mathrm{~L}^{-1}$ from the initial $54.5 \mathrm{~g} \mathrm{~L}^{-1}$ released sugar within $48 \mathrm{~h}$ (Figure 8 ). This corresponded to $98.1 \%$ of theoretical bioethanol yield with volumetric productivity of $0.50 \mathrm{~g} \mathrm{~L}^{-1} \mathrm{~h}^{-1}$. The results indicated that $S$. cerevisiae was well-suited to ferment the sugars derived from SPR residual starch into bioethanol.

Bioethanol yield was comparable and in fact slightly higher compared to that of ethanol produced by S.cerevisiae from other feedstocks i.e. red sage $\left(0.48 \mathrm{~g} \mathrm{~g}^{-1}\right)$ (Kuhad et al. 2010), corncob (0.48 $\left.\mathrm{g} \mathrm{g}^{-1}\right)$ (Chen et al. 2007) and oil palm frond (0.49 $\left.\mathrm{g} \mathrm{g}^{-1}\right)$ (Kumneadklang et al. 2015) (Table 4).

\section{OVERALL MASS BALANCE}

The results obtained from bioconversion of SPR into bioethanol via acid hydrolysis and fermentation were used to develop an overall mass balance (Figure 9). One tonne of SPR was used as a basis for the overall mass balance calculation. The optimal pretreatment/hydrolysis condition was at $125^{\circ} \mathrm{C}$ for 90 min using $1 \%\left(\mathrm{vv}^{-1}\right) \mathrm{H}_{2} \mathrm{SO}_{4}$. During acid hydrolysis $742.5 \mathrm{~kg}$ of fermentable sugars was obtained from 1 tonne of SPR. The hydrolysate was recovered and batch fermentation was performed with $S$. cerevisiae at $30^{\circ} \mathrm{C}$ for $24 \mathrm{~h}$. Fermentation using $S$. cerevisiae successfully converted the sugars with $98.1 \%$

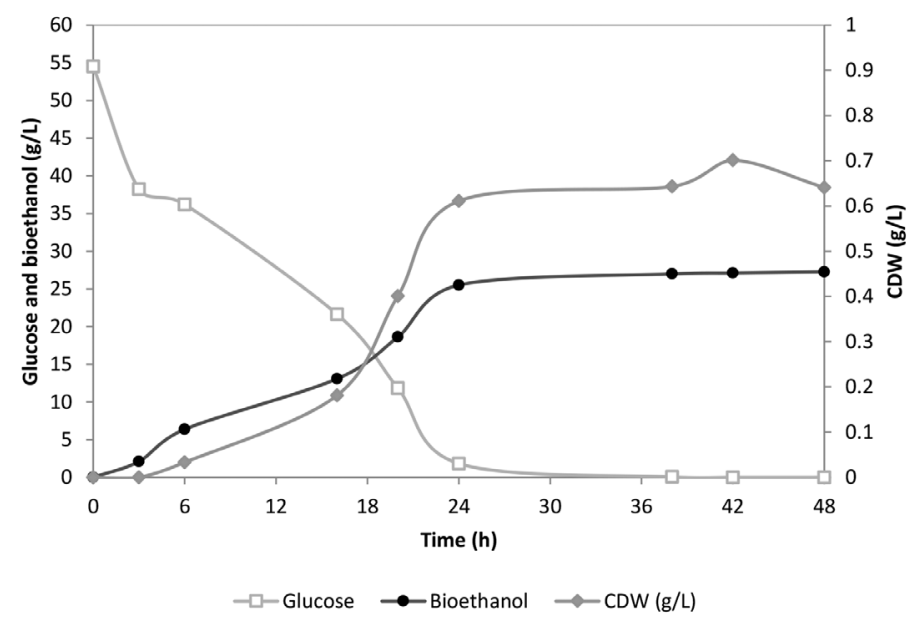

FIGURE 8 . Fermentation profile of the acid hydrolysate of sago pith residue by $S$. cerevisiae

TABLE 4. Comparison of bioethanol production by S. cerevisiae from various types of feedstocks

\begin{tabular}{|c|c|c|c|c|c|}
\hline $\begin{array}{l}\text { Feedstock/ } \\
\text { substrate }\end{array}$ & $\begin{array}{l}\text { Pre-treatment/ } \\
\text { hydrolysis step }\end{array}$ & $\begin{array}{l}\text { Sugar yield }\left(\mathrm{mg} \mathrm{g}^{-1)}\right. \\
\text { /production }\left(\mathrm{g} \mathrm{L}^{-1}\right)\end{array}$ & $\begin{array}{l}\text { Fermentation } \\
\text { scale }\end{array}$ & $\begin{array}{c}\text { Ethanol yield } \\
\left(\mathrm{g} \mathrm{g}^{-1}\right) / \text { Final titer } \\
\left(\mathrm{g} \mathrm{L}^{-1}\right)\end{array}$ & Reference \\
\hline Red sage & $\begin{array}{l}\text { Acid hydrolysis }(3 \% \\
\left.\mathrm{H}_{2} \mathrm{SO}_{4}, 120^{\circ} \mathrm{C}, 45 \mathrm{~min}\right) \\
+ \text { cellulase hydrolysis at } \\
50^{\circ} \mathrm{C}, \mathrm{pH} 5.0,28 \mathrm{~h}\end{array}$ & $187.14 \mathrm{mg} \mathrm{g}^{-1}$ & 12-L bioreactor & $\begin{array}{l}0.48 \mathrm{~g} \mathrm{~g}^{-1} \\
17.7 \mathrm{~g} \mathrm{~L}^{-1}\end{array}$ & $\begin{array}{l}\text { Kuhad et al. } \\
2010\end{array}$ \\
\hline Corncob & $\begin{array}{l}\text { Acid hydrolysis }(1 \% \\
\left.\mathrm{H}_{2} \mathrm{SO}_{4} \text { at } 108^{\circ} \mathrm{C}, 180 \mathrm{~min}\right) \\
+ \text { cellulase and cellobiase } \\
\text { hydrolysis }\end{array}$ & n.a. & n.a. & $\begin{array}{c}0.48 \\
45.7 \mathrm{~g} \mathrm{~L}^{-1}\end{array}$ & $\begin{array}{l}\text { Chen et al. } \\
2007\end{array}$ \\
\hline $\begin{array}{l}\text { Oil palm frond } \\
\text { fibre }\end{array}$ & $\begin{array}{l}\text { Alkaline treatment }(2 \% \\
\left.\mathrm{NaOH} \text { in } \mathrm{H}_{2} \mathrm{O}_{2}\right)+ \text { cellulase } \\
\text { hydrolysis at } 50^{\circ} \mathrm{C}, 150 \\
\text { rpm, } 72 \mathrm{~h}\end{array}$ & $\begin{array}{l}56.94 \mathrm{~g} \mathrm{~L}^{-1} \\
379.3 \mathrm{mg} \mathrm{g}^{-1}\end{array}$ & 2-L bioreactor & $0.49 \mathrm{~g} \mathrm{~g}^{-1}$ & $\begin{array}{l}\text { Kumneadklang } \\
\text { et al. } 2015\end{array}$ \\
\hline $\begin{array}{l}\text { Sago pith } \\
\text { residue (SPR) } \\
\text { hydrolysate }\end{array}$ & $\begin{array}{l}\text { Enzymatic hydrolysis } \\
\text { (amylase, } 72 \mathrm{~h}+\text { cellulase } \\
\text { at } 37^{\circ} \mathrm{C}, 150 \mathrm{rpm}, 48 \mathrm{~h} \text { ) }\end{array}$ & $\begin{array}{l}40.15 \mathrm{~g} \mathrm{~L}^{-1} \\
803 \mathrm{mg} \mathrm{g}^{-1}\end{array}$ & 250-mL flask & $14.3 \mathrm{~g} \mathrm{~L}^{-1}$ & $\begin{array}{l}\text { Vincent et al. } \\
2015\end{array}$ \\
\hline SPR hydrolysate & $\begin{array}{l}\text { Enzymatic hydrolysis } \\
\text { (glucoamylase, } 60^{\circ} \mathrm{C}, 60 \\
\text { min + pullulanase) }\end{array}$ & $84.75 \mathrm{~g} \mathrm{~L}^{-1}$ & n.a. & $\begin{array}{l}0.48 \mathrm{~g} \mathrm{~g}^{-1} \\
40.30 \mathrm{~g} \mathrm{~L}^{-1}\end{array}$ & $\begin{array}{l}\text { Awg-Adeni et } \\
\text { al. } 2013\end{array}$ \\
\hline SPR hydrolysate & $\begin{array}{l}\text { Acid hydrolysis }(1 \% \\
\left.\mathrm{H}_{2} \mathrm{SO}_{4}, 125^{\circ} \mathrm{C}, 90 \mathrm{~min}\right)\end{array}$ & $\begin{array}{l}733.8 \mathrm{mg} \mathrm{g}^{-1} \\
45 \mathrm{~g} \mathrm{~L}^{-1}\end{array}$ & $\begin{array}{c}6.7-\mathrm{L} \\
\text { bioreactor }\end{array}$ & $0.49 \mathrm{~g} \mathrm{~g}^{-1}$ & This study \\
\hline
\end{tabular}




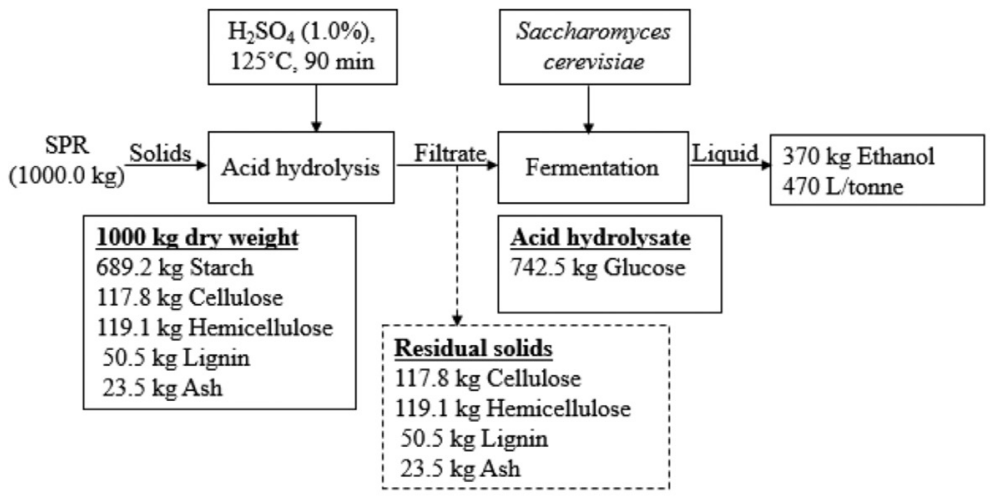

FIGURE 9. A mass balance on overall bioconversion of residual starch from sago pith residue (SPR) into bioethanol

fermentation efficiency, producing $370 \mathrm{~kg}$ of bioethanol per tonne of SPR. Based on the experimental bioethanol yield of $0.49 \mathrm{~g} \mathrm{~g} \mathrm{~g}^{-1}$, it was validated that SPR may be a potential starchy biomass for bioethanol production.

It is thus essential to further compare the sugars and bioethanol production from other biomass (Table 4). Kuhad et al. (2010) obtained only $1.87 \mathrm{~g}$ of sugar from $10 \mathrm{~g}$ of red sage acid hydrolysate despite $61.1 \%$ total carbohydrates presence in the biomass. Kumneadklang et al. (2015) obtained $3.8 \mathrm{~g}$ of sugar from $10 \mathrm{~g}$ of alkaline treated oil palm frond fibre. SPR on the other hand, contained a starchy lignocellulosic material which can easily be converted into fermentable sugar. Vincent et al. (2015) managed to obtain $8 \mathrm{~g}$ of sugar from $10 \mathrm{~g}$ SPR using enzymatic hydrolysis. Although the sugar in the previous studies reported by Awg-Adeni et al. (2013) and Vincent et al. (2015) were slightly higher compared to our study (7.34 g sugar from 10 g SPR), the enzymatic approach might not be economically attractive to the production of a low-cost fuel such as ethanol.

\section{CONCLUSION}

Findings from the present study demonstrated the potential of SPR as a renewable fermentation feedstock for bioethanol production. A substantial amount of fermentable sugars can be easily obtained from the residual starch using dilute acid hydrolysis resulting in $96 \%$ hydrolysis conversion as compared to $79 \%$ using enzymatic approach. The high ethanol yield can be achieved without supplementation of nitrogen and nutrients showing SPR hydrolysate is rich in minerals and nutrients favourable for microbial fermentation. The bioconversion of residual starch from sago processing may provide a sustainable platform in waste management that could contribute greatly to enhancing sago as an essential biofuel crop in the future.

\section{ACKNOWLEDGEMENTS}

The authors thank the Director-General of МРОв for permission to publish this paper. The authors also thank the internship students and staff of Energy and Environment Unit, MPOB for their technical assistance.

\section{REFERENCES}

Awg-Adeni, D.S., Bujang, K.B., Hassan, M.A. \& Abd-Aziz, S. 2013. Recovery of glucose from residual starch of sago hampas for bioethanol production. BioMed Research International. 2013: Article ID. 935852. http://dx.doi. org/10.1152/2013/935852.

Cecil, J. 2002. The development of technology for the extraction of sago. In New Frontiers of Sago Palm Studies, edited by Kainuma, K., Okazaki, M., Toyoda, Y. \& Cecil, J.E. Proceedings of the International Symposium on Sago (SAGO 2001). Tokyo: Universal Academy Press. pp. 83-91.

Chen, M., Xia, L. \& Xue, P. 2007. Enzymatic hydrolysis of corncob and ethanol production from cellulosic hydrolysate. International Biodeterioration \& Biodegredation 59: 85-89.

Flores, D.M. 2009. The green potentials of sago palm and sago starch. The National Biotech Week, Scientific Forum, Nido-Fortified Science Discovery Center, SM Mall of Asia. November 24, 2009.

Gupta, R., Mehta, G. \& Kuhad, R.C. 2012. Fermentation of pentose and hexose sugars from corncob, a low cost feedstock into ethanol. Biomass and Bioenergy 47: 334-3410.

Gusmayanti, E., Maherawati, Krisnohadi, A. \& Sholahuddin. 2010. Simulating bioethanol production from sago palm grown on peatland. AFITA 2010 International Conference, the Quality Information for Competition Agricultural Based Production System and Commerce.

Hebeda, R.E., Nagodawithana, T. \& Reed, G. 1993. Starches, sugars, and syrups. In Enzymes in Food Processing, 3rd ed., edited by Nagodawithana, T. \& Reed, G. New York: Academic Press Inc. pp. 321-343,

Hii, S.L., Tan, J.S., Ling, T.C \& Arbakariya, A. 2012. Pulullanse: Role in starch hydrolysis and potential industrial applications. Enzyme Research 2012: Article ID. 921362. doi:10.1155/2012/921362.

Hisajima, S. 1994. Propagation of sago palm plant. Nippon Nogei Kagaku Kaishi (Japan) 68(4): 833-836.

Khawla, B.J., Sameh, M., Imen, G., Donyes, F., Dhouha, G., Raoudha, E.G. \& Oumema, N.E. 2014. Potato peel as feedstock for bioethanol production: A comparison of acidic and enzymatic hydrolysis. Industrial Crops and Products 52: 144-149. 
Kootstra, A.M.J., Beeftink, H.H., Scott, E.L. \& Sanders, J.P.M. 2009. Comparison of dilute mineral and organic acid pretreatment for enzymatic hydrolysis of wheat straw. Biochemical Engineering Journal 46: 126-131.

Kuhad, R.C., Gupta, R., Khasa, Y.P. \& Singh,A. 2010. Bioethanol production from Lantana camara (red sage): Pretreatment, saccharification and fermentation. Bioresource Technology 101(21): 8348-8354.

Kumneadklang, S., Larpkiattaworn, S., Niyasom, C. \& O-Thong, S. 2015. Bioethanol production from oil palm frond by simultaneous saccharification and fermentation. Energy Procedia 79: 784-790.

Kumoro, A.C., Ngoh, G.C., Hasan, M., Ong, C.H. \& Teoh, E.C. 2008. Conversion of fibrous sago (Metroxylon sagu) waste into fermentable sugar via acid and enzymatic hydrolysis. Asian Journal of Scientific Research 1: 412-420.

Nurul-Adela, B.; Nasrin, A.B. \& Loh, S.K. 2016. Palm oil mill effluent as a low-cost substrate for bioflocculant production by Bacillus marisflavi NA8. Bioresour. Bioprocess 3: 20.

Ozawa, T., Takahiro, O. \& Osama, N. 1996. Hemicelluloses in the fibrous residue of sago palm. Proceedings of the Sixth International Sago Symposium, Pekan Baru, Indonesia.

Polakovič, M. \& Bryjak, J. 2004. Modelling of potato starch saccharication by an Aspergillus niger glucoamylase. Biochemical Engineering Journal 18(1): 57-63.

Sarawak Agriculture Statistics 2013. http://www.doa.sarawak. gov.my.

Singhal, R.S., Kennedy, J.F., Gopalakrishnan, S.M., Kaczmarek, A., Knill, C.J. \& Akmar, P.F. 2008. Industrial production, processing, and utilization of sago palm-derived products. Carbohydrate Polymer 72: 1-20.

Siti Mazlina, M.K., Siti Norfadhillah, M., Siti Aslina, H. \& Fakrul Razi, A. 2007. Improvement on sago flour processing. International Journal of Engineering and Technology 4: 8-14.
Vickineswary, S. \& Shim, Y.L. 1996. Growth and starch degrading activity of Myceliophthora thermophila in solidsubstrate fermentation of sago hampas. Journal of Molecular Biology and Biotechnology 42: 85-89.

Vincent, M., Senawi, B.R.A., Esut, E., Norizawati, M.N. \& Dayang Salwani,A.A. 2015. Sequential saccharification and simultaneous fermentation (SSSF) of sago hampas for the production of bioethanol. Sains Malaysiana 44(6): 899-904.

Nurul Adela Bukhari*, Soh Kheang Loh \& Nasrin Abu Bakar Energy and Environment Unit, Engineering and

Processing Research Division

Malaysian Palm Oil Board (MPOB), 6, Persiaran Institusi Bandar Baru Bangi, 43000 Kajang, Selangor Darul Ehsan Malaysia

Maizan Ismail

Crop and Livestock Integration

Integration Research and Extension Division

Malaysian Palm Oil Board (MPOB), 6, Persiaran Institusi

Bandar Baru Bangi, 43000 Kajang, Selangor Darul Ehsan Malaysia

*Corresponding author; email: adela@mpob.gov.my

Received: 14 July 2015

Accepted: 24 January 2017 